Int. J. Dev. Biol. 58: 21-27 (2014)

doi: $10.1387 / \mathrm{ijdb} .140007 \mathrm{XL}$

\title{
Generation of pluripotent stem cells via protein transduction
}

\author{
XIA LI, PENGFEI ZHANG, CHAO WEI and YUNHAI ZHANG* \\ Anhui Provincial Laboratory for Local Livestock and Poultry Genetic Resource Conservation and Breeding, \\ College of Animal Science and Technology, Anhui Agricultural University, Hefei, China
}

\begin{abstract}
The development of techniques for reprogramming somatic cells led to the birth of the cloned sheep "Dolly" and the generation of induced pluripotent stem cells (iPSCs). iPSCs hold great promise for in vitro disease modeling, new drug screening, regenerative medicine and agricultural production. These cells can differentiate into almost any tissue types and they can be used to produce autografts that will not be rejected by the patient. However, practical application has been limited by the potential for insertion mutagenesis and by the complexity of the associated procedures. A protein-based approach to generation of iPSCs could offer better prospects by avoiding these problems. This review provides an overview of the key processes and mechanism involved in protein-based somatic cell reprogramming, discusses some promising methods for increasing its efficiency and future challenges.
\end{abstract}

KEY WORDS: protein, induced pluripotent stem cell, reprogramming, small molecule, immunogenicity

\section{Introduction}

Induced pluripotent stem cells (iPSCs) are somatic cells whose characteristics are reprogrammed, by ectopic expression of defined transcription factors, to resemble those of embryonic stem cells (ESCs) (Takahashi and Yamanaka, 2006). Owing to their ability to replicate indefinitely and to differentiate into numerous cells types, generation of iPSCs is thought as one of the important breakthrough in the field of stem cell research (Geoghegan and Byrnes, 2008), along with the earlier isolation of mouse and human ESCs.

Since the first iPSCs were generated by Yamanaka and his colleagues, many types of cells from different animals were successfully induced into the pluripotent state by various methods. However, the reprogramming mechanism is unclear and some problems remain unresolved, including safety issues stemming from the integration of foreign genes into the host genome and from the usage of virus vectors. For example, Yamanaka's initial iPSCs failed to produce germline chimeras, which may have been caused by an insufficient degree of reprogramming in the iPSCs (Takahashi and Yamanaka, 2006). Thereafter, Yamanaka et al., overcame this hurdle and generated murine iPSCs with germline competency. Unfortunately, they found that approximately $20 \%$ of the offspring developed tumors attributable to reactivation of the c-Myc transgene (Okita et al., 2007).

To introduce reprogramming transcriptional factors into somatic cells while minimizing or avoiding insertion mutagenesis, several techniques using virus-free systems have been developed; these include the use of non-integrating adenoviruses (Stadtfeld et al., 2008) and Sendai viruses (Ban et al., 2011), plasmids (Okita et al., 2010), piggybac transposons (Woltjen et al., 2009) and episomal vectors (Yu et al., 2009). Although these methods reduced genome integration significantly, the DNA of the reprogramming factors (RFs) and short vectors after excision can also cause insertion mutagenesis; therefore, a DNA-free system is highly desirable. To date, virus- and transgene-free iPSCs have been derived through ectopic expression of transcriptional factors using mRNA (Warren et al., 2010, Yakubov et al., 2010), minicircle RNA (Jia et al., 2010), reprogramming proteins (Nemes et al., 2013, Zhang et al., 2012, Zhou et al., 2009) and small molecule compounds (Hou et al., 2013). The most obvious method for avoiding DNA integration into the host-cell genome is delivery of the RFs as recombinant proteins. This method can also provide great control over the concentration, timing, and combination of reprogramming transcription factors.

The critical steps in the process are the production of large quantities of pure bioactive proteins, translocation of these to the nucleus of the somatic cell, and modification of gene expression by the proteins. Large quantities of the required protein can be produced in prokaryotic and eukaryotic cells. They can be trans-

\footnotetext{
Abbreviations used in this paper: iPSCs, induced pluripotent stem cells; ESCs, embryonic stem cells; RFs, reprogramming factors; PTDs, protein transduction domains; CPPs, cell-penetrating peptides; NLS, nuclear localization signal; R, arginine; SLO, streptolysin O; HIV-TAT, human immunodeficiency virus transactivator of transcription; HS, heparin sulfate; TLR3, toll-like receptor 3; Vc, Vitamin C.
}

*Address correspondence to: Yunhai Zhang. College of Animal Science and Technology, Anhui Agricultural University, Hefei 230036, China.
Tel./Fax.: +86-551-6-5786-357. E-mail: yunhaizhang@ahau.edu.cn

Accepted: 6 March 2014. Final, author-corrected PDF published online: 30 April 2014

ISSN: Online 1696-3547, Print 0214-6282

(C) 2014 UBC Press

Printed in Spain 
ported into cells if fused in frame to protein transduction domains (PTDs) or cell-penetrating peptides (CPPs) (Beerens et al., 2003). In this review, we give an overview of protein-based somatic cell reprogramming, analyze the key steps and examine the potential for development of more efficient methods in the future.

\section{Source of reprogramming proteins}

In 1997, the birth of cloned sheep Dolly by somatic cell nuclear transfer demonstrated that terminally differentiated cells still have totipotency (Wilmut et al., 1997). In 2000, Kikyo et al., first used egg cytoplasm of Xenopus laevis to induce the reprogramming of somatic nuclei, and later extracts of various pluripotent cells, such as carcinoma cells (Freberg et al., 2007, Taranger et al., 2005) and ESCs (Rajasingh et al., 2008) were used to investigate cell dedifferentiation. Recently, many studies have shown that the proteins in these cell extracts are critical to the process of reprogramming somatic cells into iPSCs (Bui et al., 2012, Cho et al., 2010, Ganier et al., 2011, Singhal et al., 2010). However, it is not known which proteins play a decisive role.

In 2009, by using purified and defined recombinant proteins, which were produced in Escherichia coli (E. coli), Zhou et al., first reported the successful reprogramming of mouse somatic cells to a pluripotent state (Zhou et al., 2009). At present, E. coli and mammalian cells have been used to produce defined transcription proteins for iPSCs generation. The $E$. coli expression system can produce a high yield in a short time, and the protein purification procedure is simple. In 2011, Tang et al., demonstrated these features of the $E$. coli expression system and reported that the fusion-protein construct is important for their reprogramming activity (Tang et al., 2011). They found that replacing the Klf4 viral factor with the Klf4 protein fused with trans-activator of transcription (TAT) at the $\mathrm{N}$-terminus showed no reprogramming activity, whereas the fusion-protein with Discosoma red fluorescent protein between TAT and KLf4 caused significant generation of iPSCs. The cost of the E. coli expression system is low, once the construct of the protein expression vector has been produced, but it has a major disadvantage in that the recombinant proteins have to be released from inclusion bodies under denaturing conditions. The subsequent steps of protein solubilization, refolding, and purification may also affect the bioactivity of recombinant proteins. These features of the E. coli expression system have been reported in the work of Pan et al., (Pan et al., 2010). In their study, the denatured recombinant proteins showed very weak biological activity resulting in ineffective reprogramming of somatic cells. To find and solve these problems relating to biological activity, by using Oct4 recombinant protein replacing Oct4 viral factor during Sox2, Klf4 and c-Mycretroviruses factors mediated reprogramming, Thier et al., demonstrated the biological activity of Oct4 recombinant protein from E. coli (Thier et al., 2010). Subsequently, using the same method, the biological activity of Sox2 (Thier et al., 2012) and Klf4 (Tang et al., 2011) recombinant proteins were shown. A dual luciferase reporter system can be used to evaluate biological activity in vivo (Pan et al., 2010, Yang et al., 2009, Zhang et al., 2012). iPSCs can also be generated using commercially available pure proteins, also produced by the E. coli expression system (Khan et al., 2013, Lee et al., 2012). The in vitro activity of these proteins is always determined by the electrophoretic mobility shift assay.

In contrast to E. coli, the mammalian cell expression system is capable of producing correct protein folding, assembly and posttranslational modification; most recombinant protein pharmaceuticals are produced in mammalian cells (Wurm, 2004). However, the technical and financial costs, associated with purification and large-scale production, impair its application. So far, there has only been a single report of iPSCs being generated by proteins from a mammalian cell expression system (Kim et al., 2009). These researchers first generated stable HEK293 cell lines that could each express one of four RFs; then using extracts of these cells they induced reprogramming of somatic cells. It took six rounds of transduction over at least 8 weeks until iPSCs colonies were observed.

The yeast expression system is another potential option; it could offer large-scale production, eukaryotic protein folding and suitable post-translational modification (Romanos et al., 1992). However, to date, there have no reports of iPSCs generated via proteins produced in yeast.

\section{Methods of transporting proteins across membranes}

Another technical obstacle is transportation of proteins across the cell and nuclear membranes to their site of action. So far, streptolysin O (SLO), CPPs and other vectors have been used for this purpose.

For the reprogramming of somatic cells by pluripotent-cell extracts, SLO, a toxic thiol-activated membrane-poration protein, is used as the membrane-permeabilization agent (Bui et al., 2012, Cho et al., 2010, Singhal et al., 2010). In the case of SLO-mediated reversible permeabilization, damaged membranes have been shown to exhibit large, functional holes that allow for the passage of large molecules with molecular diameters exceeding $15 \mathrm{~nm}$ (Bhakdi et al., 1985, Taranger et al., 2005). This reprogramming procedure using cell extracts and SLO has the advantage of being particularly simple and efficient. For example, Cho et al., reported that a single transfer of ESC-derived proteins into primary cultures of adult mouse fibroblasts can produce fully reprogrammed iPSCs in 25 days (Cho et al., 2010). So far, there have been no reports of pure, defined proteins being inserted into target cells using SLOmediated reversible permeabilization methods.

In 1988, Frankel found that the human immunodeficiency virus transactivator of transcription (HIV-TAT) protein could penetrate the cell membrane and activate HIV-specific genes (Frankel et al., 1988, Frankel and Pabo, 1988). The key functional structure of the HIV-TAT protein is TAT, which is composed of a specific 10-20 amino acid sequence. After being added to the culture medium, TAT-fusion proteins can rapidly enter cells and achieve maximal intracellular concentrations in less than 5 min (Becker-Hapak et al., 2001). In 2001, Tyagi et al., reported that heparin sulfate (HS) proteoglycan is a receptor that causes cells to internalize the TAT protein. This was demonstrated by comparing cells with genetically impaired synthesis of HS with wild-type cells, or by using lyases that specifically degrade HS chains (Tyagi et al., 2001). Heparin was used to remove residual proteins attached to the cell surface during assessment of protein transduction (Yang et al., 2009). Then, many groups found TAT-fusion proteins could rapidly enter the cells via lipid raft-dependent macropinocytosis (Murriel and Dowdy, 2006, Wadia et al., 2004, Ziegler et al., 2005). Further studies showed that TAT-PTD sequence-enriched arginine residues and cationic CPPs primarily consist of multiple arginine and lysine 
TABLE 1

\begin{tabular}{|c|c|c|c|c|}
\hline \multicolumn{5}{|c|}{$\begin{array}{l}\text { SUMMARY OF METHODS USED FOR PROTEIN-BASED SOMATIC } \\
\text { CELL REPROGRAMMING }\end{array}$} \\
\hline $\begin{array}{l}\text { Author } \\
\text { and time }\end{array}$ & $\begin{array}{l}\text { Parent cell } \\
\text { source and } \\
\text { delivery vector }\end{array}$ & $\begin{array}{l}\text { Proteins source, } \\
\text { factors and small } \\
\text { molecules }\end{array}$ & $\begin{array}{l}\text { Treatment } \\
\text { procedure } \\
\text { Treatment cycles }\end{array}$ & $\begin{array}{l}\text { Differentiation } \\
\text { potential of } \\
\text { iPSCs }\end{array}$ \\
\hline $\begin{array}{l}\text { Zhou et al. } \\
2009\end{array}$ & $\begin{array}{l}\text { MEFs } \\
11 R\end{array}$ & $\begin{array}{l}\text { E. coli } \\
\text { OSK/OSKM } \\
\text { VPA }\end{array}$ & $\begin{array}{l}\text { 12h proteins } \\
36 \mathrm{~h} \text { without } \\
4 \text { times }\end{array}$ & Chimeric fetuses \\
\hline $\begin{array}{l}\text { Kim et al. } \\
2009\end{array}$ & $\begin{array}{l}\text { HNFs } \\
9 R\end{array}$ & $\begin{array}{l}\text { 293T cells } \\
\text { OSKM } \\
\text { None }\end{array}$ & $\begin{array}{l}16 \text { h proteins } \\
6 \text { days without } \\
6 \text { times }\end{array}$ & $\begin{array}{l}\text { Teratomas } \\
\text { EBs }\end{array}$ \\
\hline $\begin{array}{l}\text { Cho et al. } \\
2010\end{array}$ & $\begin{array}{l}\text { MCFs/MSFs } \\
\text { SLO }\end{array}$ & $\begin{array}{l}\text { ESCs- } \\
\text { derivedproteins } \\
\text { None }\end{array}$ & $\begin{array}{l}1 \text { day proteins } \\
1 \text { times }\end{array}$ & $\begin{array}{l}\text { Chimera } \\
\text { offspring }\end{array}$ \\
\hline $\begin{array}{l}\text { Zhang et al. } \\
2012\end{array}$ & $\begin{array}{l}\text { HFFs } \\
\text { TAT }\end{array}$ & $\begin{array}{l}\text { E. coli } \\
\text { OSKMN } \\
\text { VPA }\end{array}$ & $\begin{array}{l}2 \mathrm{~h} \text { proteins } \\
46 \mathrm{~h} \text { without } \\
9 \text { times }\end{array}$ & $\begin{array}{l}\text { No stable iPSCs } \\
\text { lines }\end{array}$ \\
\hline $\begin{array}{l}\text { Lee et al. } \\
2012\end{array}$ & $\begin{array}{l}\text { HFs } \\
11 R\end{array}$ & $\begin{array}{l}\text { E. coli } \\
\text { OSKM } \\
\text { Poly I:C }\end{array}$ & $\begin{array}{l}1-21 \text { days proteins } \\
1 \text { times }\end{array}$ & Teratomas \\
\hline $\begin{array}{l}\text { Khan et al. } \\
2013\end{array}$ & $\begin{array}{l}\text { HFFs } \\
\text { Cationic } \\
\text { bolaamphiphile }\end{array}$ & $\begin{array}{l}\text { E. coli } \\
\text { Nr5a2+SKN } \\
\text { None }\end{array}$ & $\begin{array}{l}\text { 3h proteins } \\
\text { None } \\
\text { 3times }\end{array}$ & $\begin{array}{l}\text { Teratomas } \\
\text { EBs }\end{array}$ \\
\hline $\begin{array}{l}\text { Je Cho et al. } \\
2013\end{array}$ & $\begin{array}{l}\text { Mouse NSCs } \\
\text { Nanotube }\end{array}$ & $\begin{array}{l}\text { E. coli } \\
\text { OSKMN } \\
\text { None }\end{array}$ & None & $\begin{array}{l}\text { No stable iPSCs } \\
\text { lines }\end{array}$ \\
\hline $\begin{array}{l}\text { Nemes et al. } \\
2013\end{array}$ & $\begin{array}{l}\text { MEFs } \\
\text { TAT }\end{array}$ & $\begin{array}{l}\text { E. coli } \\
\text { OSKMN } \\
\text { None }\end{array}$ & $\begin{array}{l}12 \mathrm{~h} \text { proteins } \\
\text { 2days without } \\
4 \text { times }\end{array}$ & $\begin{array}{l}\text { Chimeric } \\
\text { offspring }\end{array}$ \\
\hline
\end{tabular}

OSKMNL represent Oct4, Sox2, Klf4, c-Myc, Nanog, and Lin28, respectively; EBs represent embryoid bodies; HFs represent human fibroblasts; HFFs, human foreskin fibroblasts; MCFs represent mouse cardiac fibroblasts; MEF, mouse embryonic fibroblast; MSFs represent mouse skin fibroblasts; NSCs, neural stem cells. Poly I:C, polyinosinic-polycytidylic acid; R, arginine; VPA, valproic acid; None represents no related information in the research.

residues, could deliver various chemical compounds or proteins into cells (Gump and Dowdy, 2007, Wadia et al., 2004). This ability of TAT and polyarginine to deliver proteins may be explained by the structure of arginine, which possesses a head group that is known to interact with ions present on the membrane surface via a stable bidentate ion pairing (Chugh et al., 2010). However, which transduction system is most suitable for protein-based cell reprogramming remains unknown.

In 2001, Matsushita et al., demonstrated delivery of proteins into neurons in brain slices using eleven arginine $(R)$ residues; among the transduction vectors tested, TAT, 7R, 9R and 11R, the latter showed the greatest efficiency (Matsushita et al., 2001). In 2009, Zhou et al., and Kim et al., used 11R and 9R fusion proteins, respectively, to successfully generate iPSCs via recombinant proteins (Kim et al., 2009, Zhou et al., 2009). Interestingly, Zhang et al., showed that the recombinant TAT-fused RFs are, in general, transcriptionally more active than the corresponding 11R-RFs, as shown by activation of their corresponding reporter genes in dual luciferase reporter assays (Zhang et al., 2012). Recently, new delivery proteins have been investigated. In 2012, Khan et al., designed and synthesized a cationic bolaamphiphile for use as a non-viral gene delivery vector (Khan et al., 2012) and one year later, they used it to deliver RFs into fibroblasts, generating non-genetic iPSCs (Khan et al., 2013). In 2013, Je Cho's group developed a nanotube-mediated protein delivery system, which could activate genes for pluripotency in somatic cells (Cho et al., 2013). These technologies may contribute to obtain new breakthroughs in protein transduction and reprogramming efficiency.

Finally, to facilitate nuclear localization of the recombinant protein in cells, the nuclear localization signal (NLS) is always used. NLS contributes to nuclear localization of proteins without further modifications (Pan et al., 2004). By using proteins fused with the transactivator transcription-nuclear localization signal polypeptide (NLS) for generating iPSCs without gene integration, Nemes et al., found that the NLS sequence had a double role, supporting the nuclear localization of the proteins, while minimizing the endosomal/lysosomal trapping degradation of the cargo (Nemes et al., 2013). On the other hand, the technology of immunocytochemistry always used to exam whether exogenous recombinant proteins transduction into cell nucleus.

\section{Combinations of proteins that permit reprogramming}

Various combinations of reprogramming transcription factors and small molecules have been used in a number of recent studies (Table 1). In 2009, Zhou et al., obtained stable iPSCs from OG2/ Oct4-GFP reporter mouse embryonic fibroblast (MEF) cells when they were transduced with four proteins (Oct4, Sox2, KIf4 and c-Myc) and treated with valproic acid (VPA). However, they did not obtain stable GFP ${ }^{+}$iPSC colonies by transduction with three (Oct4, Sox2 and Klf4) or all four reprogramming proteins under the same conditions, although GFP-negative cell colonies were observed (Zhou et al., 2009). In addition, those GFP-negative cell colonies stained positive with ALP, an early pluripotency marker, suggesting they might be partially reprogrammed cells. In 2012 , after failing to obtain iPSC-like colonies from human foreskin fibroblasts (HFFs) using the same four proteins, Zhang et al., added a fifth transcription factor, Nanog, and in the presence of VPA, which allowed for generation of iPSCs from HFFs (Zhang et al., 2012). Subsequently, Je Cho et al., used three (Oct4, Sox2 and Nanog) and five (Oct4, Sox2, Klf4, c-Myc and Nanog) transcription proteins to induce reprogramming of neural stem cells from OG2/Oct4-GFP reporter transgenic mice, and only five-protein treatment induced GFP-positive colonies (Cho et al., 2013). These results suggest Nanog is important in reprogramming procedure, and previous studies reported that Nanog is the gateway to the pluripotent ground state (Sanges and Cosma, 2010, Silva et al., 2009). Recently, Costa et al., also provide an insight into the reprogramming mechanism of Nanog that the function of Nanog depends on TET1 and TET2 in establishment of pluripotency (Costa et al., 2013). On the other hand, the research of Li et al., demonstrated that the initiate of mesenchymal-to-epithelial transition (MET) is required for the nuclear reprogramming of mouse fibroblasts ( $\mathrm{Li}$ et al., 2010). Furthermore, Liu et al., reported that a sequential introduction protocol (Oct4-KIf4 first, then $c-M y c$ and finally Sox2) outperforms the simultaneous method and introduce the concept of a sequential EMT-MET (epithelial-to-mesenchymal transition, EMT) mechanism for cell reprogramming (Liu et al., 2013). Whether this protocol applies to the protein-based reprogramming approach needs further study.

To date, the four factors, Oct4, Sox2, Klf4 and c-Myc have been commonly employed for somatic cell reprogramming, but other factors have also been shown to be important. Zheng et al., found that only recombinant human fibromodulin protein could indcuce conversion of human fibroblasts into multipotent cells (Zheng et al., 2012). Compared with virus-based iPSCs, these cells expressed pluripotent markers, formed embryonic bodies and differentiated into all three germ layers in vitro; however, they proliferated slowly and did not form teratomas. In 2013, Wang et al., found that Nr5 $\alpha 2$ plays an important role in pig iPSCs generation (Wang et al., 2013). 
Later, Khan and colleagues demonstrated that Nr5a2 protein can replace Oct4 in the reprogramming procedure (Khan et al., 2013).

Conservation of the active proteins is another important issue. In vitro degradation and in vivo breakdown by cellular machinery need to be accounted for when developing reprogramming methods. Therefore, the concentrations and treatment times for recombinant proteins are critical. Zhou et al., found that 11R-tagged recombinant proteins could translocate into the nucleus at $8 \mu \mathrm{g} / \mathrm{ml}$ within $6 \mathrm{~h}$ and they appeared to be stable inside cells for up to $48 \mathrm{~h}$ (Zhou et al., 2009). In another study, efficient intracellular translocation of all recombinant proteins was observed within $8 \mathrm{~h}$, and most proteins were translocated into the nucleus (Kim et al., 2009). Zhang and colleagues demonstrated that incubation with $50 \mathrm{nM}$ TAT protein for $2 \mathrm{~h}$ was sufficient to obtain the maximum concentration in cells, and primarily nuclear localization (Zhang et al., 2012).

Protein-based reprogramming technology is playing a more and more important role in iPSCs generation. In the development of virus-mediated reprogramming methods, after initially focusing on the quality and quantity of the iPSCs, many researchers switched their attention to the cellular type, small molecule compounds, and the transcription-factor (protein) cocktail. Similarly, for proteinbased reprogramming technology, the choice of small molecule and protein cocktail is key to its efficacy.

\section{Small molecule compounds for improved reprogramming}

To date, in protein-based reprogramming procedures, only VPA and polyinosinic-polycytidylic acid (poly I:C) have been used by researchers. VPA, a widely used histone deacetylase inhibitor, can significantly enhance reprogramming efficiency (Huangfu et al., 2008b). For the three-factor (Oct4, Sox2 and Klf4) and fourfactor (Oct4, Sox2, KIf4 and c-Myc) treatments, addition of VPA for one week can improve the percentage of Oct4-GFP-positive cells by more than 100-fold and 50-fold, respectively (Huangfu et al., 2008a). In addition, germline transmission was achieved using VPA-treated iPSCs from three factors (Oct4, Sox2, KIf4) infected MEF cells. In another study, VPA was shown to enable reprogramming of primary human fibroblasts with just two transcription factors, Oct4 and Sox2 (Huangfu et al., 2008b). They found that VPA can greatly increase the efficiency of reprogramming somatic cells to a pluripotent state and replace some of the transcription factors used to reprogram differentiated cells during virus-based reprogramming. Similar results were observed in the procedure of proteins mediated reprogramming. In 2009, Zhou et al., found that GFP-positive colonies were only obtained in the presence of VPA when MEFs were transduced with four or three proteins (Zhou et al., 2009). VPA was also be used in the method of Zhang et al., (Zhang et al., 2012). The effect of VPA on reprogramming may be due to the combined effects of upregulation of ESC-specific genes and downregulation of MEF-specific genes. In seeking to further improve reprogramming efficiency, Lee et al., (2012) demonstrated that the toll-like receptor 3 (TLR3) pathway enables efficient induction of pluripotency by viral or mRNA approaches. Poly I:C is a synthetic analog of double stranded RNA that is recognized specifically by TLR3 (Alexopoulou et al., 2001). After adding this TLR3 agonist to the protein cocktail, Lee et al., found that the reprogramming efficiency of their protein-induction method was increased and that colony formation begun after a shorter time (Lee et al., 2012).
For viral induction of reprogramming, an array of chemical compounds have been investigated for their ability to improve the efficiency of iPSCs generation. For example, the use of two inhibitors, SB431542 and PD325901, can improve efficiency by 100 -fold during reprogramming of human fibroblasts; when thiazovivin was also added, this increase in efficiency rose to 200 -fold (Lin et al., 2009). Similar results have been reported for other small molecules in somatic reprogramming protocols. In 2010, Mali et al., reported that butyrate could enhance iPSCs formation from 15- to 51-fold when using either retroviral or piggyBac transposon vectors expressing four to five reprogramming genes (Mali et al., 2010). Wang et al., found that treatment with 8-bromoadenosine $3^{\prime}, 5^{\prime}$-cyclic monophosphate and VPAincreases the reprogramming efficiency to 6.5-fold compared with the control group (Wang and Adjaye, 2011).

Vitamin C (Vc), an important micronutrient, can also increase reprogramming efficiency (Esteban et al., 2010, Wang et al., 2011). In 2013, Chen and colleagues established direct connections between $\mathrm{Vc}$, ten-eleven translocation (Tet) and DNA methylation, thus putting forward a new pathway for understanding the molecular mechanisms of somatic cell reprogramming (Chen et al., 2013). However, Vc and other chemical compounds have not been used for protein-based reprogramming methods. Further study is needed to find more chemical compounds that could enhance protein-based reprogramming.

\section{The perspective of protein-based iPSCs}

Conventional viral- and transgene- mediated methods of generating iPSCs not only pose the risk of viral reactivation, but also may cause insertion mutagenesis. As a result, these iPSCs are potentially tumorigenic. To render the technique clinically applicable, safe methods of generating iPSCs are essential. The newer reprogramming methods based on protein transduction do not involve viruses or genome integration, giving them the potential to produce safe and consistent iPSCs. However, its low reprogramming efficiency was one of the biggest challenges. To our knowledge, only about nine groups have reported obtaining iPSCs via protein transduction, and these studies have been restricted to the cells of mice and humans, with only VPA and Poly I:C being tested as small molecule enhancers of the proteins' efficiency. Therefore, more cellular materials of various species, and new vectors and small molecule compounds should be used to design efficient and robust methods for protein-based cell reprogramming. Besides, to further propel the development of protein-based iPSCs clinical applications, a feeder-independent and serum-free culture system (Totonchi et al., 2010, Yamasaki et al., 2013, Zhang et al., 2014), and a dimethyl sulfoxide-free and no animal-derived components cryopreservation system (Nishigaki et al., 2011) should be tested. While ultimate goals of iPSCs is the treatment of human diseases, the time of obtaining patient-specific iPSCs by protein-based approach needs to be shortened on account of the serious conditions they could treat and the lives they could save.

The immunogenicity of iPSCs is also a critical problem for their clinical application. Zhao et al., reported that mouse ESCs can efficiently form teratomas in the same type mouse without any evident immune rejection, and teratomas formed by the mouse iPSCs by retroviral approach were mostly immune-rejected (Zhao et al., 2011). In addition, the teratomas, which formed by iPSCs by 
episomal approach that cause no genomic integration, were small and apparent regression by 40 days after iPSCs implantation. These results showed that iPSCs has higher immunogenicity than ESCs, and iPSCs produced via retroviral methods are more immunogenic than those generated via non-integrating elements. Research has also shown that humans immune system has natural immunity to pluripotency antigen Oct4 (Dhodapkar et al., 2010). Therefore, the high immunogenicity of genomic integration iPSCs may be caused by the sustained expression of the exogenous transcription factors. In contrast, the latest researches have reported that iPSCs and the differentiation cells from no genomic integration iPSCs have low immunogenicity (Araki et al., 2013, Guha et al., 2013). Whether the protein approach leads to lower immunogenicity needs to be studied further.

\section{Conclusion}

Taken together, the birth of iPSCs techniques and their rapid development has opened a promising window for human genetic disease modeling, regenerative medicine, drugs screening, and agricultural production. The safety issue of iPSCs leads to the birth of pluripotent stem cells via protein transduction. Although the protein-based iPSCs technique has evolved over more than four years, it is still in the early stages of development. This may attribute to its complexity, involving the information of molecular and stem cell theory, proteomics, epigenetics and immunology. Therefore, we recommend the formation of interdisciplinary collaborations between experts from the fields of protein engineering, molecule, stem cells, epigenetics and immunology, as a means to achieve better and faster development of safe iPSCs. If the various technical difficulties can be resolved, we are confident that the viraland transgene-free iPSCs by protein-based induction technique will play an important role in the field of medicine and agriculture.

\section{Acknowledgement}

We thank Shaoshuai Jiang, Fei Han, Yu Zhang, Yong Pu and Yunsheng Li for helpful reading of the manuscript. This study was supported by the National Natural Science Foundation of China (Grant No. 31272442).

\section{References}

ARAKI, R., UDA, M., HOKI, Y., SUNAYAMA, M., NAKAMURA, M., ANDO, S., SUGIURA, M., IDENO, H., SHIMADA, A., NIFUJI, A. et al., (2013). Negligible immunogenicity of terminally differentiated cells derived from induced pluripotent or embryonic stem cells. Nature 494: 100-104.

BAN, H., NISHISHITA, N., FUSAKI, N., TABATA, T., SAEKI, K., SHIKAMURA, M., TAKADA, N., INOUE, M., HASEGAWA, M., KAWAMATA, S. et al., (2011). Efficient generation of transgene-free human induced pluripotent stem cells (iPSCs) by temperature-sensitive Sendai virus vectors. Proc Natl Acad Sci USA 108: 14234-14239.

BECKER-HAPAK, M., MCALLISTER, S.S. and DOWDY, S.F. (2001). TAT-mediated protein transduction into mammalian cells. Methods 24: 247-256.

BEERENS, A.M., AL HADITHY, A.F., ROTS, M.G. and HAISMA, H.J. (2003). Protein transduction domains and their utility in gene therapy. Curr Gene Ther 3: 486-494.

BHAKDI, S., TRANUM-JENSEN, J. and SZIEGOLEIT, A. (1985). Mechanism of membrane damage by streptolysin-O. Infect Immun 47: 52-60.

BUI, H.T., KWON, D.N., KANG, M.H., OH, M.H., PARK, M.R., PARK, W.J., PAIK, S.S., VAN THUAN, N. and KIM, J.H. (2012). Epigenetic reprogramming in somatic cells induced by extract from germinal vesicle stage pig oocytes. Development 139: $4330-4340$.

CHEN, J., GUO, L., ZHANG, L., WU, H., YANG, J., LIU, H., WANG, X., HU, X., GU, T., ZHOU, Z. et al., (2013). Vitamin C modulates TET1 function during somatic cell reprogramming. Nat Genet 45: 1504-1509.

CHO, H.J., LEE, C.S., KWON, Y.W., PAEK, J.S., LEE, S.H., HUR, J., LEE, E.J., ROH, T.Y., CHU, I.S., LEEM, S.H. et al., (2010). Induction of pluripotent stem cells from adult somatic cells by protein-based reprogramming without genetic manipulation. Blood 116: 386-395.

CHO, S.J., CHOI, H.W., CHO, J., JUNG, S., SEO, H.G. and DO, J.T. (2013). Activation of pluripotency genes by a nanotube-mediated protein delivery system. $\mathrm{Mol}$ Reprod Dev 80: 1000-1008.

CHUGH, A., EUDES, F. and SHIM, Y.S. (2010). Cell-penetrating peptides: Nanocarrier for macromolecule delivery in living cells. IUBMB Life 62: 183-193.

COSTA, Y., DING, J., THEUNISSEN, T.W., FAIOLA, F., HORE, T.A., SHLIAHA, P.V., FIDALGO, M., SAUNDERS, A., LAWRENCE, M., DIETMANN, S. et al., (2013). NANOG-dependent function of TET1 and TET2 in establishment of pluripotency. Nature 495: 370-374.

DHODAPKAR, K.M., FELDMAN, D., MATTHEWS, P., RADFAR, S., PICKERING, R., TURKULA, S., ZEBROSKI, H. and DHODAPKAR, M.V. (2010). Natural immunity to pluripotency antigen OCT4 in humans. Proc Nat/Acad Sci USA 107: 8718-8723.

ESTEBAN, M.A., WANG, T., QIN, B., YANG, J., QIN, D., CAI, J., LI, W., WENG, Z., CHEN, J., NI, S. et al., (2010). Vitamin C enhances the generation of mouse and human induced pluripotent stem cells. Cell Stem Cell 6: 71-79.

FRANKEL, A.D., BREDT, D.S. and PABO, C.O. (1988). Tat protein from human immunodeficiency virus forms a metal-linked dimer. Science 240: 70-73.

FRANKEL, A.D. and PABO, C.O. (1988). Cellular uptake of the tat protein from human immunodeficiency virus. Cell 55: 1189-1193.

FREBERG, C.T., DAHL, J.A., TIMOSKAINEN, S. and COLLAS, P. (2007). Epigenetic reprogramming of OCT4 and NANOG regulatory regions by embryonal carcinoma cell extract. Mol Biol Cell 18: 1543-1553.

GANIER, O., BOCQUET, S., PEIFFER, I., BROCHARD, V., ARNAUD, P., PUY, A., JOUNEAU, A., FEIL, R., RENARD, J.P. and MECHALI, M. (2011). Synergic reprogramming of mammalian cells by combined exposure to mitotic Xenopus egg extracts and transcription factors. Proc Natl Acad Sci USA 108: 17331-17336.

GEOGHEGAN, E. and BYRNES, L. (2008). Mouse induced pluripotent stem cells. Int J Dev Biol 52: 1015-1022.

GUHA, P., MORGAN, J.W., MOSTOSLAVSKY, G., RODRIGUES, N.P. and BOYD, A.S. (2013). Lack of immune response to differentiated cells derived from syngeneic induced pluripotent stem cells. Cell Stem Cell 12: 407-412.

GUMP, J.M. and DOWDY, S.F. (2007). TAT transduction: the molecular mechanism and therapeutic prospects. Trends Mol Med 13: 443-448.

HOU, P., LI, Y., ZHANG, X., LIU, C., GUAN, J., LI, H., ZHAO, T., YE, J., YANG, W., LIU, K. et al., (2013). Pluripotent stem cells induced from mouse somatic cells by small-molecule compounds. Science 341: 651-654.

HUANGFU, D., MAEHR, R., GUO, W., EIJKELENBOOM, A., SNITOW, M., CHEN, A.E. and MELTON, D.A. (2008a). Induction of pluripotent stem cells by defined factors is greatly improved by small-molecule compounds. Nat Biotechnol 26: 795-797.

HUANGFU, D., OSAFUNE, K., MAEHR, R., GUO, W., EIJKELENBOOM, A., CHEN, S., MUHLESTEIN, W. and MELTON, D.A. (2008b). Induction of pluripotent stem cells from primary human fibroblasts with only Oct4 and Sox2. Nat Biotechnol 26: 1269-1275.

JIA, F., WILSON, K.D., SUN, N., GUPTA, D.M., HUANG, M., LI, Z., PANETTA, N.J., CHEN, Z.Y., ROBBINS, R.C., KAY, M.A. et al., (2010). A nonviral minicircle vector for deriving human iPS cells. Nat Methods 7: 197-199.

KHAN, M., ANG, C.Y., WIRADHARMA, N., YONG, L.K., LIU, S., LIU, L., GAO, S. and YANG, Y.Y. (2012). Diaminododecane-based cationic bolaamphiphile as a non-viral gene delivery carrier. Biomaterials 33: 4673-4680.

KHAN, M., NARAYANAN, K., LU, H., CHOO, Y., DU, C., WIRADHARMA, N., YANG, Y.-Y. and WAN, A.C.A. (2013). Delivery of reprogramming factors into fibroblasts for generation of non-genetic induced pluripotent stem cells using a cationic bolaamphiphile as a non-viral vector. Biomaterials 34: 5336-5343.

KIM, D., KIM, C.H., MOON, J.I., CHUNG, Y.G., CHANG, M.Y., HAN, B.S., KO, S., YANG, E., CHA, K.Y., LANZA, R. et al., (2009). Generation of Human Induced Pluripotent Stem Cells by Direct Delivery of Reprogramming Proteins. Cell Stem Cell 4: 472-476.

LEE, J., SAYED, N., HUNTER, A., AU, K.F., WONG, W.H., MOCARSKI, E.S., PERA, R.R., YAKUBOV, E. and COOKE, J.P. (2012). Activation of Innate Immunity Is Required for Efficient Nuclear Reprogramming. Cell 151: 547-558. 
LI, R., LIANG, J., NI, S., ZHOU, T., QING, X., LI, H., HE, W., CHEN, J., LI, F., ZHUANG, Q. et al., (2010). A mesenchymal-to-epithelial transition initiates and is required for the nuclear reprogramming of mouse fibroblasts. Cell Stem Cell 7: 51-63.

LIN, T., AMBASUDHAN, R., YUAN, X., LI, W., HILCOVE, S., ABUJAROUR, R., LIN, X., HAHM, H.S., HAO, E., HAYEK, A. et al., (2009). A chemical platform for improved induction of human iPSCs. Nat Methods 6: 805-808.

LIU, X., SUN, H., QI, J., WANG, L., HE, S., LIU, J., FENG, C., CHEN, C., LI, W., GUO, Y. et al., (2013). Sequential introduction of reprogramming factors reveals a time-sensitive requirement for individual factors and a sequential EMT-MET mechanism for optimal reprogramming. Nat Cell Biol 15: 829-838.

MALI, P., CHOU, B.K., YEN, J., YE, Z., ZOU, J., DOWEY, S., BRODSKY, R.A., OHM, J.E., YU, W., BAYLIN, S.B. et al., (2010). Butyrate greatly enhances derivation of human induced pluripotent stem cells by promoting epigenetic remodeling and the expression of pluripotency-associated genes. Stem Cells 28: 713-720.

MATSUSHITA, M., TOMIZAWA, K., MORIWAKI, A., LI, S.T., TERADA, H. and MATSUI, $\mathrm{H}$. (2001). A high-efficiency protein transduction system demonstrating the role of PKA in long-lasting long-term potentiation. J Neurosci 21: 6000-6007.

MURRIEL, C.L. and DOWDY, S.F. (2006). Influence of protein transduction domains on intracellular delivery of macromolecules. Expert Opin Drug Deliv 3: 739-746.

NEMES, C., VARGA, E., POLGAR, Z., KLINCUMHOM, N., PIRITY, M.K. and DINNYES, A. (2013). Generation of Mouse Induced Pluripotent Stem Cells by Protein Transduction. Tissue Eng Part C Methods 12: 12.

NISHIGAKI, T., TERAMURA, Y., NASU, A., TAKADA, K., TOGUCHIDA, J. and IWATA, H. (2011). Highly efficient cryopreservation of human induced pluripotent stem cells using a dimethyl sulfoxide-free solution. Int J Dev Biol 55: 305-311.

OKITA, K., HONG, H., TAKAHASHI, K. and YAMANAKA, S. (2010). Generation of mouse-induced pluripotent stem cells with plasmid vectors. Nat Protoc 5: 418-428.

OKITA, K., ICHISAKA, T. and YAMANAKA, S. (2007). Generation of germline-competent induced pluripotent stem cells. Nature 448: 313-U1.

PAN, C., LU, B., CHEN, H. and BISHOP, C.E. (2010). Reprogramming human fibroblasts using HIV-1 TAT recombinant proteins OCT4, SOX2, KLF4 and c-MYC. Mol Biol Rep 37: 2117-2124.

PAN, G., QIN, B., LIU, N., SCHOLER, H.R. and PEI, D. (2004). Identification of a nuclear localization signal in OCT4 and generation of a dominant negative mutant by its ablation. J Biol Chem 279: 37013-37020.

RAJASINGH, J., LAMBERS, E., HAMADA, H., BORD, E., THORNE, T., GOUKASSIAN, I., KRISHNAMURTHY, P., ROSEN, K.M., AHLUWALIA, D., ZHU, Y. et al., (2008). Cell-free embryonic stem cell extract-mediated derivation of multipotent stem cells from NIH3T3 fibroblasts for functional and anatomical ischemic tissue repair. Circ Res 102: 15.

ROMANOS, M.A., SCORER, C.A. and CLARE, J.J. (1992). Foreign gene expression in yeast: a review. Yeast 8: 423-488.

SANGES, D. and COSMA, M.-P. (2010). Reprogramming cell fate to pluripotency: the decision-making signalling pathways. Int J Dev Biol 54: 1575-1587.

SILVA, J., NICHOLS, J., THEUNISSEN, T.W., GUO, G., VAN OOSTEN, A.L., BARRANDON, O., WRAY, J., YAMANAKA, S., CHAMBERS, I. and SMITH, A. (2009). Nanog is the gateway to the pluripotent ground state. Cell 138: 722-737.

SINGHAL, N., GRAUMANN, J., WU, G., ARAUZO-BRAVO, M.J., HAN, D.W., GREBER, B., GENTILE, L., MANN, M. and SCHOLER, H.R. (2010). Chromatin-Remodeling Components of the BAF Complex Facilitate Reprogramming. Cell 141: 943-955.

STADTFELD, M., NAGAYA, M., UTIKAL, J., WEIR, G. and HOCHEDLINGER, K. (2008). Induced pluripotent stem cells generated without viral integration. Science 322: 945-949.

TAKAHASHI, K. and YAMANAKA, S. (2006). Induction of pluripotent stem cells from mouse embryonic and adult fibroblast cultures by defined factors. Cell126:663-676.

TANG, Y., LIN, C.J. and TIAN, X.C. (2011). Functionality and transduction condition evaluation of recombinant Klf4 for improved reprogramming of iPS cells. Cellular Reprogramming 13: 99-112.

TARANGER, C.K., NOER, A., SORENSEN, A.L., HAKELIEN, A.M., BOQUEST, A.C. and COLLAS, P. (2005). Induction of dedifferentiation, genomewide transcriptional programming, and epigenetic reprogramming by extracts of carcinoma and embryonic stem cells. Mol Biol Cell 16: 5719-5735.

THIER, M., MUNST, B. and EDENHOFER, F. (2010). Exploring refined conditions for reprogramming cells by recombinant Oct4 protein. Int J Dev Biol 54: 1713-1721.
THIER, M., MUNST, B., MIELKE, S. and EDENHOFER, F. (2012). Cellular reprogramming employing recombinant sox2 protein. Stem Cells Int 549846: 29.

TOTONCHI, M., TAEI, A., SEIFINEJAD, A., TABEBORDBAR, M., RASSOULI, H. FARROKHI, A., GOURABI, H., AGHDAMI, N., HOSSEINI SALEKDEH, G. and BAHARVAND, H. (2010). Feeder- and serum-free establishment and expansion of human induced pluripotent stem cells. Int J Dev Biol 54: 877-886.

TYAGI, M., RUSNATI, M., PRESTA, M. and GIACCA, M. (2001). Internalization of HIV-1 tat requires cell surface heparan sulfate proteoglycans. J Biol Chem 276: 3254-3261.

WADIA, J.S., STAN, R.V. and DOWDY, S.F. (2004). Transducible TAT-HA fusogenic peptide enhances escape of TAT-fusion proteins after lipid raft macropinocytosis. Nat Med 10: 310-315.

WANG, J., GU, Q., HAO, J., JIA, Y., XUE, B., JIN, H., MA, J., WEI, R., HAI, T., KONG, Q. et al., (2013). Tbx3 and Nr5alpha2 play important roles in pig pluripotent stem cells. Stem Cell Rev 9: 700-708.

WANG, T., CHEN, K., ZENG, X., YANG, J., WU, Y., SHI, X., QIN, B., ZENG, L., ESTEBAN, M.A., PAN, G. et al., (2011). The histone demethylases Jhdm1a/1b enhance somatic cell reprogramming in a vitamin-C-dependent manner. Cell Stem Cell 9: 575-587.

WANG, Y. and ADJAYE, J. (2011). A cyclic AMP analog, 8-Br-cAMP, enhances the induction of pluripotency in human fibroblast cells. Stem Cell Rev 7: 331-341.

WARREN, L., MANOS, P.D., AHFELDT, T., LOH, Y.H., LI, H., LAU, F., EBINA, W. MANDAL, P.K., SMITH, Z.D., MEISSNER, A. et al., (2010). Highly efficient reprogramming to pluripotency and directed differentiation of human cells with synthetic modified mRNA. Cell Stem Cell 7: 618-630.

WILMUT, I., SCHNIEKE, A.E., MCWHIR, J., KIND, A.J. and CAMPBELL, K.H. (1997) Viable offspring derived from fetal and adult mammalian cells. Nature 385:810-813.

WOLTJEN, K., MICHAEL, I.P., MOHSENI, P., DESAI, R., MILEIKOVSKY, M., HAMALAINEN, R., COWLING, R., WANG, W., LIU, P.T., GERTSENSTEIN, M. et al., (2009). piggyBac transposition reprograms fibroblasts to induced pluripotent stem cells. Nature 458: 766-U106.

WURM, F.M. (2004). Production of recombinant protein therapeutics in cultivated mammalian cells. Nat Biotechnol 22: 1393-1398.

YAKUBOV, E., RECHAVI, G., ROZENBLATT, S. and GIVOL, D. (2010). Reprogramming of human fibroblasts to pluripotent stem cells using mRNA of four transcription factors. Biochem Biophys Res Commun 394: 189-193.

YAMASAKI, S., NABESHIMA, K., SOTOMARU, Y., TAGUCHI, Y., MUKASA, H., FURUE, M.K., SATO, J.D. and OKAMOTO, T. (2013). Long-term serial cultivation of mouse induced pluripotent stem cells in serum-free and feeder-free defined medium. Int J Dev Biol 57: 715-724.

YANG, W.C., PATEL, K.G., LEE, J., GHEBREMARIAM, Y.T., WONG, H.E., COOKE, J.P. and SWARTZ, J.R. (2009). Cell-free production of transducible transcription factors for nuclear reprogramming. Biotechnol Bioeng 104: 1047-1058.

YU, J., HU, K., SMUGA-OTTO, K., TIAN, S., STEWART, R., SLUKVIN, II and THOMSON, J.A. (2009). Human induced pluripotent stem cells free of vector and transgene sequences. Science 324: 797-801.

ZHANG, H., MA, Y., GU, J., LIAO, B., LI, J., WONG, J. and JIN, Y. (2012). Reprogramming of somatic cells via TAT-mediated protein transduction of recombinant factors. Biomaterials 33: 5047-5055.

ZHANG, Y., WEI, C., ZHANG, P., LI, X., LIU, T., PU, Y., LI, Y., CAO, Z., CAO, H., LIU, Y. et al., (2014). Efficient Reprogramming of Naive-Like Induced Pluripotent Stem Cells from Porcine Adipose-Derived Stem Cells with a Feeder-Independent and Serum-Free System. PLoS One 9.

ZHAO, T., ZHANG, Z.N., RONG, Z. and XU, Y. (2011). Immunogenicity of induced pluripotent stem cells. Nature 474: 212-215.

ZHENG, Z., JIAN, J., ZHANG, X., ZARA, J.N., YIN, W., CHIANG, M., LIU, Y., WANG, J., PANG, S., TING, K. et al., (2012). Reprogramming of human fibroblasts into multipotent cells with a single ECM proteoglycan, fibromodulin. Biomaterials 33 : 5821-5831.

ZHOU, H.Y., WU, S.L., JOO, J.Y., ZHU, S.Y., HAN, D.W., LIN, T.X., TRAUGER, S. BIEN, G., YAO, S., ZHU, Y. et al., (2009). Generation of Induced Pluripotent Stem Cells Using Recombinant Proteins. Cell Stem Cell 4: 381-384.

ZIEGLER, A., NERVI, P., DURRENBERGER, M. and SEELIG, J. (2005). The cationic cell-penetrating peptide CPP(TAT) derived from the HIV-1 protein TAT is rapidly transported into living fibroblasts: optical, biophysical, and metabolic evidence. Biochemistry 44: 138-148. 


\section{Further Related Reading, published previously in the Int. J. Dev. Biol.}

Exploring refined conditions for reprogramming cells by recombinant Oct4 protein Marc Thier, Bernhard Münst and Frank Edenhofer Int. J. Dev. Biol. (2010) 54: 1713-1721

http://dx.doi.org/10.1387/ijdb.103193mt

Feeder- and serum-free establishment and expansion of human induced pluripotent stem cells

Mehdi Totonchi, Adeleh Taei, Ali Seifinejad, Mohammadsharif Tabebordbar, Hassan Rassouli, Ali Farrokhi, Hamid Gourabi, Nasser Aghdami, Ghasem Hosseini-Salekdeh and Hossein Baharvand

Int. J. Dev. Biol. (2010) 54: 877-886

http://dx.doi.org/10.1387/ijdb.092903mt

Highly efficient cryopreservation of human induced pluripotent stem cells using a dimethyl sulfoxide-free solution

Tatsuya Nishigaki, Yuji Teramura, Akira Nasu, Kei Takada, Junya Toguchida and Hiroo Iwata Int. J. Dev. Biol. (2011) 55: 305-311

http://dx.doi.org/10.1387/ijdb.103145tn

Mouse induced pluripotent stem cells

Eamon Geoghegan and Lucy Byrnes

Int. J. Dev. Biol. (2008) 52: 1015-1022

http://dx.doi.org/10.1387/ijdb.082640eg

Reprogramming cell fate to pluripotency: the decision-making signalling pathways Daniela Sanges and Maria-Pia Cosma

Int. J. Dev. Biol. (2010) 54: 1575-1587

http://dx.doi.org/10.1387/ijdb.103190ds

5 yr ISI Impact Factor $(2011)=2.959$
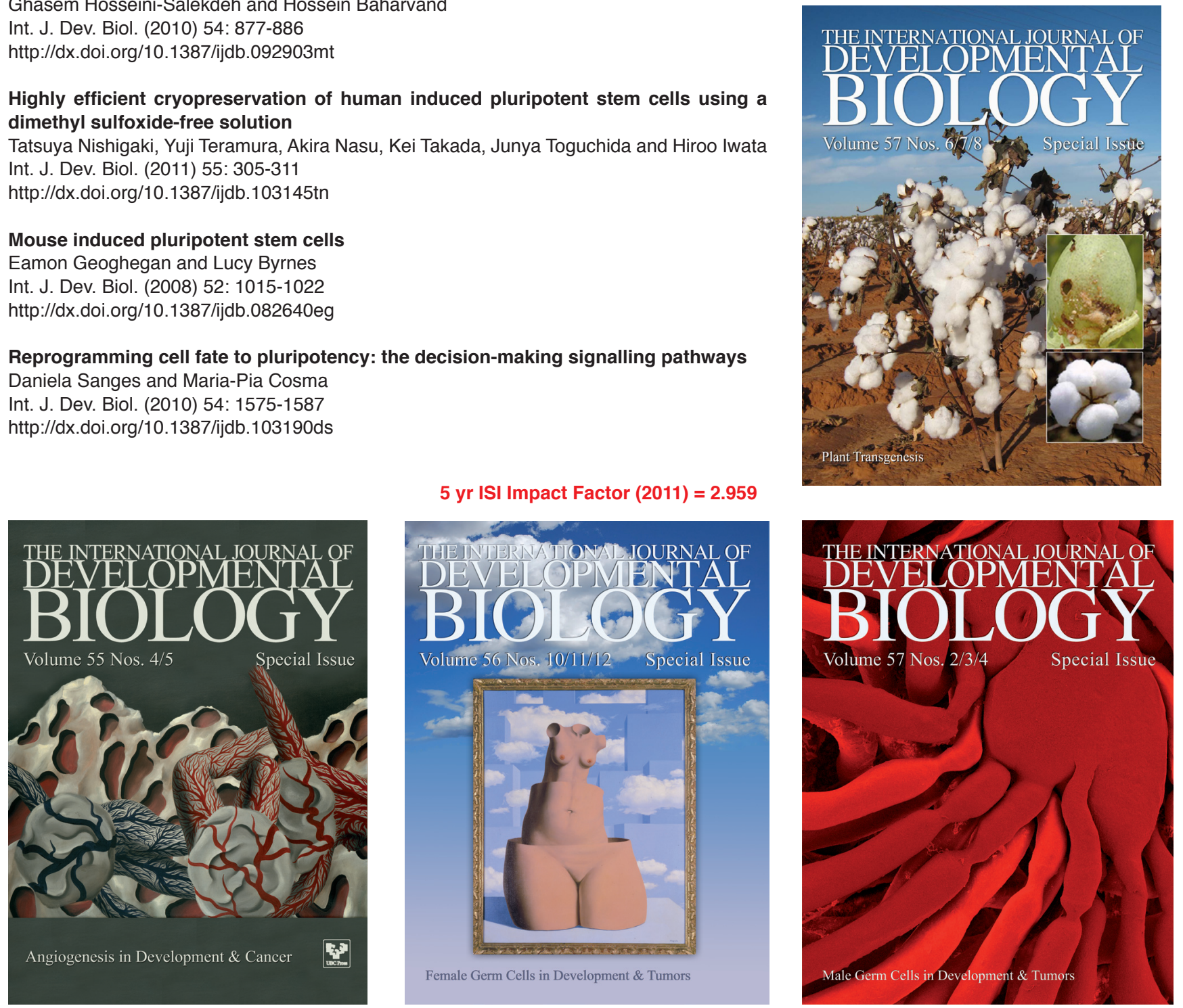